\title{
Innovation in the companies provided by the fusion: Design Thinking and Design Management
}

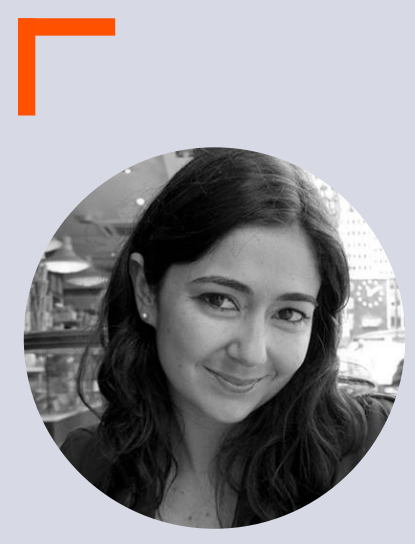

\section{Sara Gancho}

Doutoramento, IADE - Universidade Europeia IADE/UNIDCOM

sara.gancho@universidadeeuropeia.pt

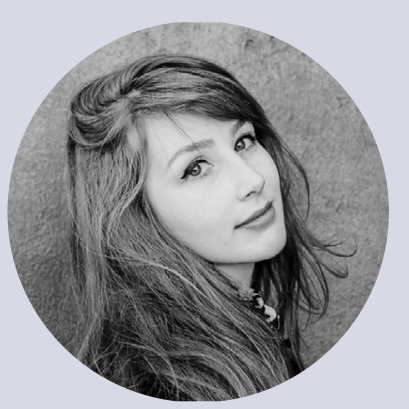

\section{Monique Gasparelli}

IADE - Universidade Europeia mgasparelli@gmail.com 


\section{Abstract}

In order to maintain competitiveness, companies look for various strategies to differentiate themselves from the competition and stand out in the market. In this why, design and the way it is managed are elements of great importance, since design, besides the aesthetic aspects, began to include strategy within the business world. Problem-solving tactics through design focused on developing innovations only provided positive returns for organizations. With the present article, one can see the contribution of design management and design thinking for the companies to reach innovative solutions.

\section{Keywords}

Design management; design thinking; innovation; business success;

\section{Resumo}

Para manter a competitividade, as empresas procuram diversas estratégias para se diferenciarem da concorrência e se destacarem no mercado. Nesse sentido, o design e a forma como ele é gerido são elementos de grande importância, uma vez que o design, além dos aspectos estéticos, passou a incluir a estratégia dentro do mundo dos negócios. As táticas de resolução de problemas através do design focado no desenvolvimento de inovações fornecem apenas retornos positivos para as organizações. Com o presente artigo, pode-se ver a contribuição da gestão de design e design thinking para as empresas alcançarem soluções inovadoras.

\section{Palavras-chave}

Design management; Design thinking; Inovação; Sucesso nos negócios; 


\section{Introduction}

The term 'design' is part of our daily lives. It is diffused around us by showing qualities, activities, and services that, even if they have or do not have primordial characteristics of 'design', are named in this way to add value. However, few are those who know the real meaning of the word, where their attributions are not restricted to the result of a process since previously it is a model of structured thoughts and actions, that travels along a precise and often unpredictable path until the desired result. Its applications are of great relevance for the business context, in which, to obtain prominence in the market, is used different competitive strategies. This article stipulates a link between management, design and innovation to achieve the objective of the theme: to relate design management with design thinking in order to provide innovative and effective solutions, in view of the factors promoted by their use within companies, guided by the perspective of the authors addressed within the several articles and books we researched. The methodology of exploratory research was used, combined with the bibliographical one, in which it was possible to investigate, develop and clarify concepts and ideas under the vision of design, management, and innovation.

\section{Design}

Martins and Merino (2008) state that design is an articulated and multidisciplinary activity that operates in the strategic and operational plans of the company, according to its vision and mission, developing products consistent with current tendencies, deadlines, and costs, transmitting the appropriate image to the public. It can be applied both globally and unitarily, seeking to create and organize means for the success of the production. One can then agree when Vianna (2012) states that the designer sees as a problem everything that impairs or impedes experience (emotional, cognitive, aesthetic) and well being in people's lives (considering various aspects of life, such as work, leisure, relationships, culture, etc.). This makes it your main task to identify problems and generate solutions. The principles of design are exposed by Stanford d.school as: 

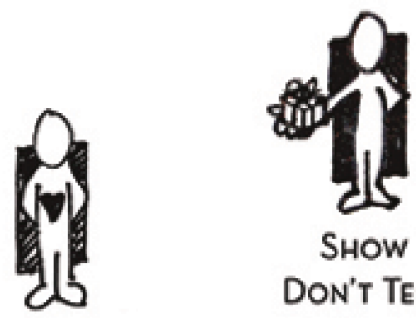

SHOW DON'T TELL

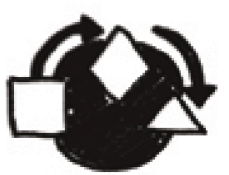

EMBRACE EXPERIMENTATION
Focus ON

Human Values

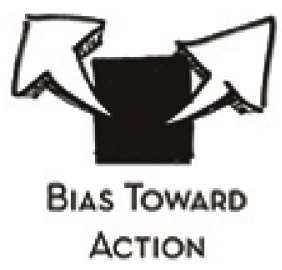

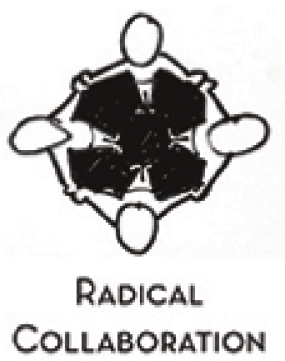

Collaboration

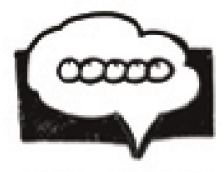

BE MindFul

OF PROCESS

\section{d.MINDSETS}

Fonte: Stanford d. school ( Hasso Plattner, 2011).

- Focus on human values: Understanding of the human being together with feedback from users.

- Show and don't tell: Communicate through impacting and meaningful experiences.

- Create clarity from complexity: Produce a coherent view of confusing problems and shape them in ways that inspire others.

- Get experimental and experiential: Prototyping is not simply a way of validating the idea, it is an integral part of the innovative process.

- Be mindful of process: Know the methods to use and what the objectives are.

- Bias toward action: Doing and acting.

Collaborate across boundaries: Gather people from diverse backgrounds and points of view, generating a plurality of opinions, ideas, and solutions. 


\subsection{Design Vs. Management}

For Lindner (2007), the designer needs to specialize as a manager, qualifying to coordinate and integrate the design activities in the organization. Being a complex interdisciplinary activity and being present in several fields of organizations, the design is introduced more and more in companies with the intention of generating intelligent and viable solutions, which makes it very similar to the management, since both follow a systematic process, logical and orderly. Mozota (2011) presents the following:

\begin{tabular}{|l|l|}
\hline \multicolumn{1}{|c|}{ Design Concepts } & \multicolumn{1}{c|}{ Management Concepts } \\
\hline Troubleshooting activity & Process, problem-solving \\
\hline Creative activity & Idea management, innovation \\
\hline Systemic activity & Business system, information \\
\hline Coordination activity & Communication, structure \\
\hline Cultural and artistic activity & $\begin{array}{l}\text { Consumer Preferences, Identity, } \\
\text { Organizational }\end{array}$ \\
\hline
\end{tabular}

Table 1: Similarity between design and management (Mozota, 2011)

Both involve elements with a large number of parameters, variables, balancing needs often conflicting (such as cost and performance, aesthetics and ease of use, materials, and durability) and the ability to choose with many possible solutions. Formerly operational by nature, the design has become a model for thinking, executing and managing the business. Designers contribute to the generation of new concepts, management and activities are focused on the life cycle of products, services or systems, driving business strategies. The management and design techniques are ideal for this to take place in order to support the processes in the creation of objective, conceptual and collaborative knowledge, where the innovation contemplates generation of ideas and the multidisciplinary work of teams until the implementation of the solution. 


\subsection{Design Management}

Fascioni (2013) states that design management proposes strategic insertions of the designer in all activities, processes and products within companies to assist in the discovery of solutions in all areas (positioning, costs, production, etc.) managing the development of services and products of the organization, integrating them from the design of a project and its launch, to its environmental impact, being efficient to create and implement a corporate culture. Design management aims to establish managerial practices focused on: "improving the design process, thus creating opportunities for the development of high quality innovative products through effective processes". (Cooper, et al., 2017).

According to Keller (2003), it is the responsibility of the design manager to build a lasting brand leadership, where knowledge about consumer needs and desires are deepened and strategic objectives achieved through constant innovation. The Design Management Handbook (1997) adds that it is necessary to establish guiding threads that link innovation to the business world. One such thread is design management. According to Phillips (2008), it is through design management that the designer participates in the construction of the vision, strategy and competitive advantages of the corporation, since it has by necessity and function to observe, identify, evaluate and act on all aspects of a company. According to Best (2015), design management is active in three levels:

\begin{tabular}{|c|l|}
\hline Strategic & $\begin{array}{l}\text { Global policies, mission, and agen- } \\
\text { da are defined. It expresses visions, } \\
\text { values, and beliefs of the organization, } \\
\text { searching for new ways of transmit- } \\
\text { ting the message to the consumer. }\end{array}$ \\
\hline Operational & $\begin{array}{l}\text { The team, process, and systems of } \\
\text { a specific business unit come into } \\
\text { play and design are used tactically } \\
\text { to help achieve organizational go- } \\
\text { als in a manner integrated with the } \\
\text { organization's strategies. }\end{array}$ \\
\hline
\end{tabular}




\begin{tabular}{|l|l|}
\hline Tactical & $\begin{array}{l}\text { It manifests itself in physical and tangi- } \\
\text { ble products, in the implementation of } \\
\text { projects and processes that the custo- } \\
\text { mer can actually touch. Management } \\
\text { is focused primarily on design's project } \\
\text { and is the first step in incorporating } \\
\text { design into the organizational environ- } \\
\text { ment and launching new products. }\end{array}$ \\
\hline
\end{tabular}

Table 2: Three Levels of Design Management (Best, 2015).

At all levels, innovation is the product, where the design manager must construct routines capable of acting as an instrument for integration of tools, in order to transform the process into something informative and dynamic. In Brown's (2010) conception, it would not be possible to conduct a business solely on the basis of intuition and inspiration, and it is in this sense that integral thinking emerges with an additional path: design thinking.

\subsection{Design Thinking}

Edgar Papke (2018) says that Design thinking is about the creative strategies that designers use during their design process. It is an approach that is used to consider issues that can help problem solving. It can be applied to business as well as social issues. Design thinking in business uses the designer's sensibility and methods to uncover people's needs with what is technologically possible making a viable business strategy that can increase customer value and market opportunity.

Design thinking is different from the analytical and linear problem solving approaches that can be wildly found in business schools (Glen, Suciu, \& Baughn, 2014).

The emerging concept of design thinking looks beyond the confines of the design professions and designer-client relationships and suggests a wider role for design in addressing our biggest societal challenges. Design is not just about solving problems; it can also be about problem-finding. Design and designers can redefine problems to arrive at better solutions and outcomes, Chick, A., \& Micklethwaite, P. (2017).

Design Thinking can be seen as an approach to innovation (eg. Kelley and Littman, 2001, Brown, 2008), as well as a universal problem solving approach (Martin, 2009; Liedtka and Ogilvie, 2011; Liedtka et al., 2013). 
For Martin (2009) design thinking promotes the balance between analytical and intuitive thinking, allowing organizations to generate innovations to increase efficiency and competitiveness, using a designer's sensitivity and methods to solve problems and meet the needs of people in a commercially viable way. In other words, design thinking is human-driven innovation. Brown (2008) points out that for design thinking to generate innovation, an approach based on behavioral analysis, human needs and preferences must be adopted. He proposes a sequence of ordered steps:

Figure 2: Design Thinking Steps
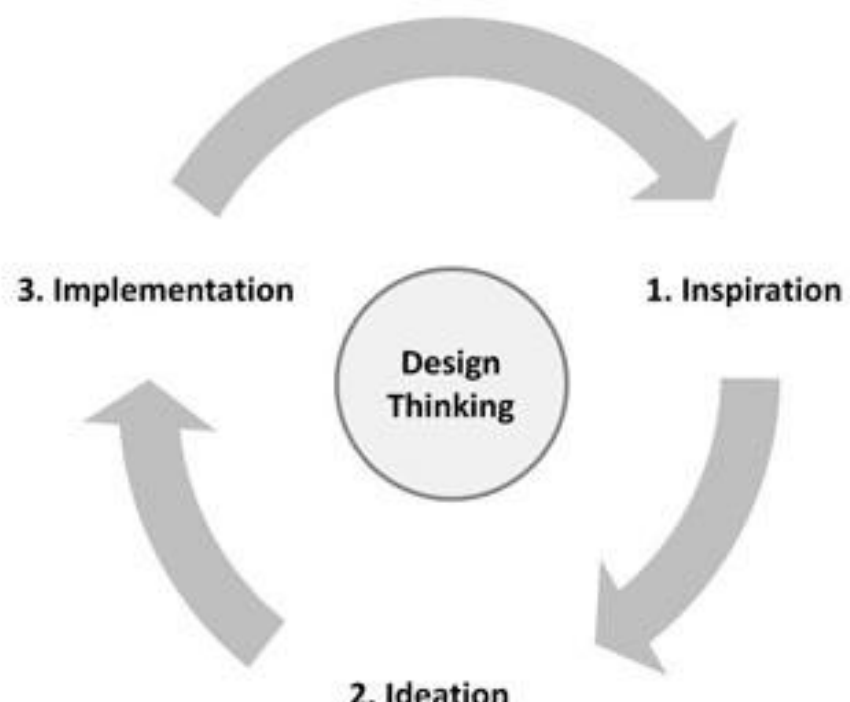

2. Ideation

Fonte: Brown, 2008

1. INSPIRATION: which motivates the search for solutions

2. IDEALIZATION: generate, develop and test ideas

3. IMPLEMENTATION: from design studio to market

Ambrose and Harris (2011) add that within these steps we need to define, research, generate ideas, test prototypes, select, implement and learn, and during the process, it is important to carry out experimentation, seek opportunities to co-create with customers and consumers, and mix large and small projects, thus managing an innovative chain that extends from short-term to long-term ideas. For an effective realization, Martin (2009) determines that the design thinker should have as tools 
the observation, imagination, and configuration, defined as seeing and listening carefully, creatively inferring with test cycles and translating the idea into an activity system that will produce the desired business result.

Figl ure $2 \cdot$ The cix-nhase iterative decion-thinking nroresc

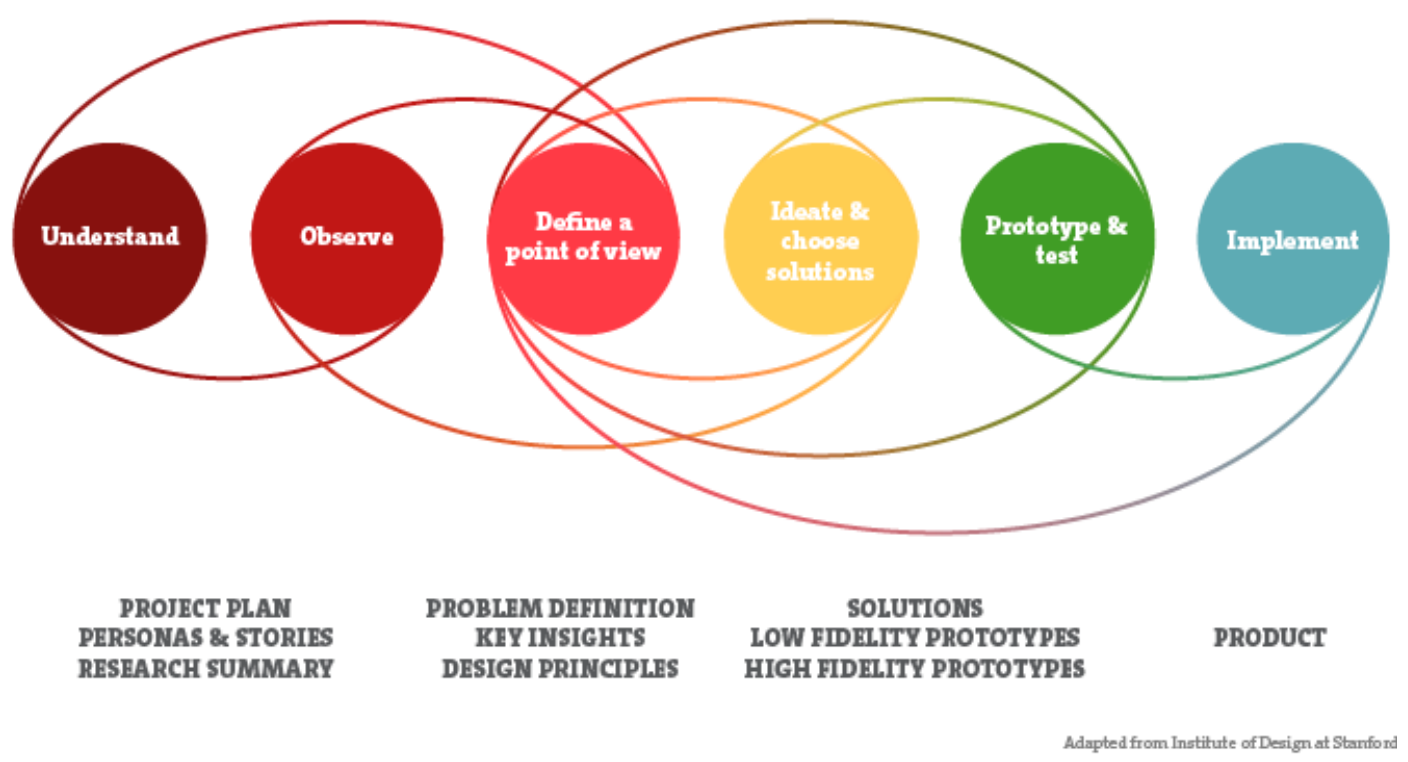

Fonte: Hasso Plattner Institute Academy, 2014

As seen above a more developed model with a six-phase iterative processes that constitute the foundation for different design-thinking processes. We follow the six-phase process suggested by a leading design thinking school at Hasso Plattner: understand, observe, define a point of view, ideate, prototype, and test, as seen above. Schumacher, T., \& Mayer, S. (2018)

\section{Innovation}

To be successful, an innovation process must deliver three things: "superior solutions, lower risks and costs of change, and employee buy-in". The business world has tried to developed useful tactics in order to achieve those outcomes. But when trying to apply them, organizations frequently encounter new obstacles and trade-offs, Liedtka (2018).

According to Thomas Lockwood and Edgar Papke (2017) innovation comes in gradual steps and often companies are expecting faster changes. 
Design is considered fundamental to innovation, which is also considered important to economic competitiveness. Policy makers and leading companies alike are committed to design-led innovation, particularly in the so-called creative industries, Chick, A., \& Micklethwaite, P. (2017).

Ropelato, Silveira, and Machado (2010) explain that innovation is a determining factor in the success of companies. They affirm that it is not enough to produce efficiently, offering quality and a greater series of products, it needs to be offered novelties, improvements, or even new features. Adopting innovations means generating, developing, and deploying ideas or procedures. These may be new products, services, technologies, structures or administrative systems. In this way, innovation is an alternative to promote changes in the organization, either for the purpose of responding to changes in internal or external environments, or an anticipated action to competitors. Wylant (2008) classifies them as:

\begin{tabular}{|c|l|}
\hline CONTINUOUS & $\begin{array}{l}\text { Small improvement over some- } \\
\text { thing that already exists, such as a } \\
\text { new taste of chewing gum. }\end{array}$ \\
\hline DYNAMICALLY CONTINUOUS & $\begin{array}{l}\text { Great improvement of existing } \\
\text { functionality, such as the introduc- } \\
\text { tion of LCD monitors over the tube } \\
\text { monitors }\end{array}$ \\
\hline DISCONTINUOUS & $\begin{array}{l}\text { A significant new technology that } \\
\text { leads to new uses and functiona- } \\
\text { lities, such as the introduction of } \\
\text { the Internet in the midst of infor- } \\
\text { mation technology. }\end{array}$ \\
\hline
\end{tabular}

Table 3: Innovation Classifications (Wylant, 2008).

Creating new problem solutions and generating ideas does not mean they will be innovative. They must produce value and be apt for application. (Innosupport, 2013). For Schumpeter (1982) it is difficult to achieve innovation regularly, mainly technological, therefore, organizations are looking for design-based, meaning-centered innovation. For excellence, design is an innovative development activity that goes beyond appearance, encompassing strategic aspects of business. This is because problem-solving techniques and designing of design thinking and design management solutions have brought a number of benefits to companies with respect to developing user-focused inno- 
vations and their needs. Consumers are more attentive and authors of consumption itself, valuing more and more the aesthetic, symbolic and emotional. This behavior mobilizes companies to apply design language strategies as a tactic of differentiation. Those who seek to reinvent themselves and encourage the generation of ideas, stimulate and help people to think differently. Since innovation is a differential for business survival and competitiveness, it must be perceived by the consumer, not only in the form or function of a product but also in symbolic aspects, through strategic and related actions, aiming at the adequacy to their demands and consolidation of the brand image. Keller and Kotler (2006) point out that when innovations are developed, they take time to spread through the social system. The authors note that the adoption of innovations by consumers goes through five stages, and it is up to the organization to facilitate this transition:

Table 4: Perception of innovation

\begin{tabular}{|l|l|}
\hline \multicolumn{1}{|c|}{ STEPS } & \multicolumn{1}{c|}{ The CONSUMER } \\
\hline 1. AWARENESS & $\begin{array}{l}\text { Knows about innovation, but has } \\
\text { no information about it }\end{array}$ \\
\hline 2. INTEREST & $\begin{array}{l}\text { Is encouraged to look for informa- } \\
\text { tion on innovation }\end{array}$ \\
\hline 3. EVALUATION & $\begin{array}{l}\text { Consider whether you will expe- } \\
\text { rience innovation }\end{array}$ \\
\hline 4. EXPERIMENTATION & $\begin{array}{l}\text { Experiment with innovation to } \\
\text { better assess your value }\end{array}$ \\
\hline 5. ADOPTION & $\begin{array}{l}\text { Decides whether to make full or } \\
\text { regular use of innovation }\end{array}$ \\
\hline
\end{tabular}

Fonte: Keller and Kotler, 2006

Innovation can be very expensive and a great risk. The new challenges products face can be unpredictable (Kotler and Armstrong, 2018). For example, by one estimate, 60 percent of all new consumer packaged products introduced by established companies fail; two-thirds of new product concepts are never even launched, David Meer, Edward C. Landry, and Samrat Sharma (2015).

It is fundamental that the proposals generated through design thinking and design management takes into account constraints, as it happens in every design project. According to Brown (2009), these can be visualized in function of three criteria, where a balance must be sought: 
Table 5: Restrictive Criteria for Innovation

\begin{tabular}{|l|l|}
\hline PRACTICABILITY & Functionally possible \\
\hline VIABILITY & Suitability of the business model \\
\hline DESIRABILITY & Awakening of people's interest \\
\hline
\end{tabular}

Fonte: Brown, 2009

Such criteria are similarly used by the Stanford Design Institute (d.school) to achieve design innovation.

Figure 4: Innovation in design Adapted from Stanford d.school

\section{Design Innovation Process}

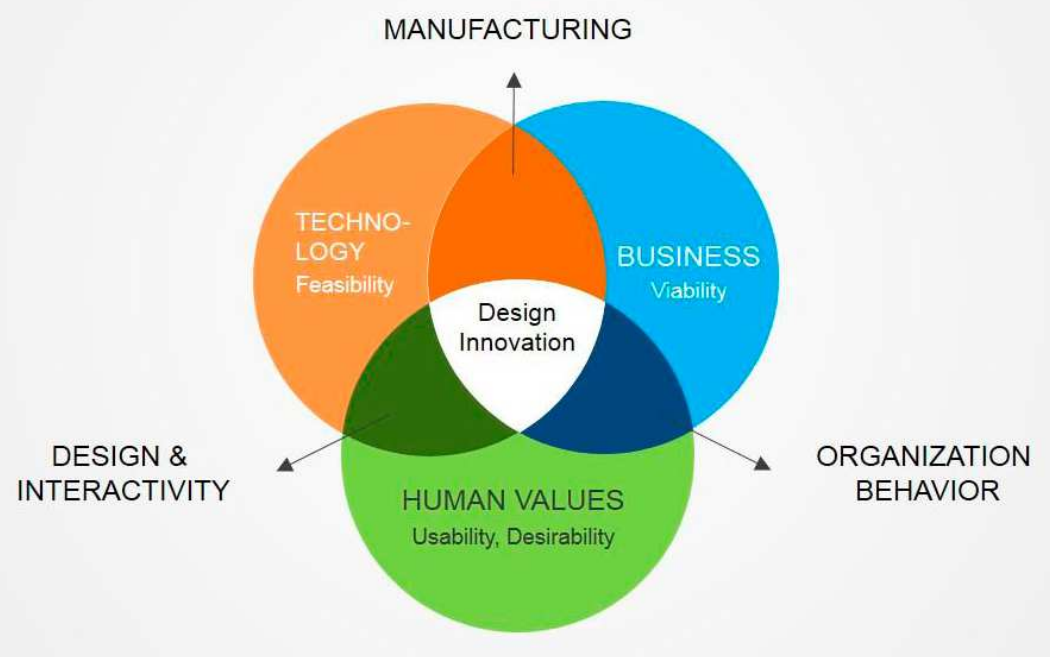

\subsection{Innovation and Creativity}

According to Chibás (2000), people tend to unify the meanings of innovation and creativity, but the two are distinct. Creativity refers to internal processes of creation itself, elaboration of ideas, projects, and causes, while innovation refers to the results, products or effects of creativity. 
Design development involves a high degree of creativity, in a controlled and process-driven way, making creativity a tool for innovation. Creative thinking, in order to flow as an individual's ability to result in innovation, must be aided by the interrelationship of design management and thinking processes. Using implicit, explicit, tactical, and objective knowledge, the designer can enhance and intensify his creativity in design processes.

\section{Fusion of Design Processes}

The design thinker and the design manager work together, engaging in procedural steps in which they acquire knowledge, formulate hypotheses, evaluate and codify them. In sequence, the ability to focus on the future arises, in order to bring the institution to innovation. To achieve this in order to build innovation value (whether continuous, dynamically continuous or discontinuous), a better product is created. According to Brown (2010), design thinking is divided into "3 spaces of innovation": inspiration, idealization, and implementation. Based on the concepts presented, it's interesting to understand how the principles of these stages relate directly to design management:

\begin{tabular}{|l|l|l|}
\hline \multirow{2}{*}{ STAGES } & \multicolumn{2}{|c|}{ DESIGN } \\
\cline { 2 - 3 } & \multicolumn{1}{|c|}{ THINKING } & \multicolumn{1}{c|}{ MANAGEMENT } \\
\hline INSPIRATION & $\begin{array}{l}\text { Understanding how } \\
\text { people experience } \\
\text { the world physically, } \\
\text { cognitively, and } \\
\text { emotionally, and how } \\
\text { Social and cultural } \\
\text { groups function } \\
\text { through collected }\end{array}$ & $\begin{array}{l}\text { Strategic: Analysis of } \\
\text { patterns, trends, and } \\
\text { behaviors that can } \\
\text { inspire solutions. The } \\
\text { manager-designer } \\
\text { is aware of his } \\
\text { surroundings since } \\
\text { different situations } \\
\text { can provide insights } \\
\text { for the solution of the } \\
\text { insights. }\end{array}$ \\
\hline
\end{tabular}




\begin{tabular}{|l|l|l|}
\hline IDEALIZATION & $\begin{array}{l}\text { Synthesize collected } \\
\text { information and } \\
\text { generate ideas for } \\
\text { the project. At this } \\
\text { stage, it is important } \\
\text { to have a diverse } \\
\text { and multidiscipli- } \\
\text { nary group involved } \\
\text { in the process }\end{array}$ & $\begin{array}{l}\text { Tactical: } \text { Realization } \\
\text { of the synthesis of } \\
\text { the ideas of the pre- } \\
\text { vious stage, where } \\
\text { divergent visions } \\
\text { depart for the gene- } \\
\text { ration of convergent } \\
\text { ideas for the project. }\end{array}$ \\
\hline IMPLEMENTATION & $\begin{array}{l}\text { Creation and deve- } \\
\text { lopment of proto- } \\
\text { types. They are cri- } \\
\text { tical to testing and } \\
\text { refining the ideas } \\
\text { generated. Once fi- } \\
\text { nalized, the strategy } \\
\text { to explain the ideas } \\
\text { is developed. They } \\
\text { aid in minimizing er- } \\
\text { rors and coming up } \\
\text { with a potential idea } \\
\text { without running out } \\
\text { of resources. }\end{array}$ & $\begin{array}{l}\text { Operational: Creation } \\
\text { adn development of } \\
\text { the prototypes of the } \\
\text { project and develop- } \\
\text { ment of the commu- } \\
\text { nication strategy of } \\
\text { the ideas developed. }\end{array}$ \\
\hline
\end{tabular}

Table 5: Relationship thinking-management.

So, connecting design thinking with design management is to focus on innovation and focus on people. It involves the discovery of needs, creation of new visions and alternative scenarios that can guide the organization around the individuals. Design management, with this approach, is no longer only concerned with managing and leading design organizations, processes and effects, and begins to worry about the imprecise beginning of the process, aiding the reinvention of organizations.

Therefore, achieving this fusion clarifies the role of design in the company, making it usable as a strategy. According to Gimeno (2000), it provides better competitive conditions; contributes to differentiation from competition; streamlining production processes, reducing costs and colla- 
borating in the search for leadership; optimizes communication; improves a product, increasing its perception of value; allows different people to collaborate; improves the company's image internally and externally.

\begin{tabular}{|c|l|}
\hline COMPANY & $\begin{array}{l}\text { Help to reach or exceed the level of competition; } \\
\text { promote the status of innovative company by mana- } \\
\text { gement style; contribute to the environment through } \\
\text { solutions; internal and external communication. }\end{array}$ \\
\hline IMAGE & $\begin{array}{l}\text { They give a good perception of the company's image } \\
\text { to the market, employees, suppliers, and competi- } \\
\text { tors; optimize product and company identification; } \\
\text { inform and optimize messages. }\end{array}$ \\
\hline PRODUCT & $\begin{array}{l}\text { They optimize new product development and pro- } \\
\text { duction initiatives, reduce launch time, lower costs, } \\
\text { add value and innovation, add quality to their cha- } \\
\text { racteristics. }\end{array}$ \\
\hline CONSUMER & $\begin{array}{l}\text { They act on the perception and value of the image, } \\
\text { value of the product, fidelity to the brand, facilitate } \\
\text { the communication, corroborate to improve the } \\
\text { quality of life. }\end{array}$ \\
\hline ECONOMY & $\begin{array}{l}\text { Increased competition potential of the industry in } \\
\text { the domestic and foreign market for innovation, } \\
\text { differential and quality standard. }\end{array}$ \\
\hline
\end{tabular}

Table 6: Benefits of the fusion: design thinking and design management

This quest for innovation is a key advantage in a market with tough competition. The benefits translate into the transition from traditional to innovative and creative. In this relationship, it is clear that design thinking can provide a great service to organizations by emphasizing the strategic level of design management, and the integration of both into the corporate culture, therefore, includes innovative solutions and added value in business processes. 
Thomas Lockwood and Edgar Papke (2017) believe that Design Thinking is able to empower people to participate in ideation or problem-solving. Design Thinking is solving the right problems with the resources that are available, it offers a path to resolving a conflict. The design thinking process is able to create a platform for constructive management of diverse thinking and strategies.

\section{Conclusion}

The use of Design thinking is mainly aligned with innovation, according to innovation scholars the implementation of Design thinking would be difficult for an organization as starting to think differently about innovation. Design thinking is able to explore the uncertain and may also be difficult to integrate into an efficient and productivity set environment. Adopting Design Thinking as a concept will allow to make the abstract - concrete. The concept of Design thinking can be viewed as a vehicle of change and may open new ways for working with innovation, Carlgreen, Lisa (2013).

Applying design thinking as a management tool and strategy is already a reality. The appreciation of the designer for his comprehensive view of problems has become essential to new business models. Designing does not just mean creating. It is necessary to identify, understand desires and needs, and develop knowledge in order to apply the imaginative capacity to overcome the limits imposed. We must think of the whole and act in search of an innovative solution. In summary, it is verified that to understand how design thinking and design management collaborate with each other in order to develop innovations, it is essential to assimilate what is design and how the designer thinks.

According to Lobach (2001) design can be understood as the realization of an idea in the form of projects. For a company, it is a producer of new ideas. It is thus up to design management to identify ways that can contribute to strategic business development, defining management techniques that enhance competitiveness through the use of design as a strategic tool. Together with design thinking, which according to Martin (2009), promotes the balance between analytical and intuitive thinking, allowing to generate innovations, a decisive factor for differentiation. The broader the vision of the system in which the process is inserted, 
the more evident the problems that need to be solved and the more innovative the solutions will be found. Together, they provide the innovation, since this article shows that design management is closely related to design thinking and that establishing this link brings benefits to the business model.

Design thinking emphasizes engagement, dialogue, and learning. By involving customers and other stakeholders in the definition of the problem and the development of solutions, design thinking offers a broad commitment to change. Allowing a structure to the innovation process, design thinking helps innovators collaborate and follow on what is essential to the outcome at every phase. It does this not only by overcoming workplace politics but by shaping the experiences of the innovators, and of their key stakeholders and implementers, at every step.

\section{References}

AMBROSE, Gavin; HARRIS, Paul. Design Thinking. Porto Alegre: Bookman, 2011.

Best, K. (2015). Design management: Managing design strategy, process, and implementation. London: Fairchild Books.

BROWN, Tim. Design Thinking. Harvard Business Review, Junho 2008. Disponível em: http://www.books.mec.biz/downloads/Harvard_ Business_Review_(_How_To_Deliver_on_a_ great_Plan_)_N\%C2\%BO_ juin_2008/MzA4NTcxOTM3 Acesso em: 22 de dezembro de 2017. BROWN, Tim. Change by Design: How Design Thinking Transforms Organizations and Inspires Innovation. Harper Business, 2009. BROWN, Tim. Design thinking: uma metodologia poderosa para decretar o m das velhas ideias. Rio de Janeiro: Elsevier, 2010. BROWN, T. Design thinking: uma metodologia poderosa para decretar o m das velhas ideias. Rio de Janeiro: Elsevier, 2010.

BROWN, T.; WYATT, J. Design thinking for Social Innovation. Stanford Social Innovation Review. California: Leland Stanford Jr. University, 2010. Carlgreen, L. (2013). Design Thinking as an Enabler of Innovation: Exploring the concept and its relation to building innovation capabilities. Chalmers University of Technology.

CENTRO PORTUGUÊS DE DESIGN. Manual de Gestão do design. Portu- 
gal, 1997.

CHIBÁS ORTIZ, Felipe. Barreiras à Comunicação e Criatividade Organizacional: um estudo em hotéis brasileiros e cubanos. São Paulo, 2000. Dissertação [Mestrado] - Programa Pós-Graduação em Integração da América Latina (PROLAM), Universidade de São Paulo.

Cooper, R., Junginger, S., Lockwood, T., Buchanan, R., Boland, R., \& Chung, K. W. (2017). The Handbook of design management. London: Bloomsbury Academic.

David Meer, Edward C. Landry, and Samrat Sharma, "Creating What Consumers Want," Forbes, January 26, 2015, www.forbes.com/sites/ strategyand/2015/01/26/ creating-what-consumers-want/.

DESIGN MANAGEMENT INSTITUTE (DMI). What is design management?. Disponível em: . Acesso em 22 dezembro 2017.

Chick, A., \& Micklethwaite, P. (2017). Design for Sustainable Change: How Design and Designers Can Drive the Sustainability Agenda. London: Bloomsbury Visual Arts.

D.SCHOOL, STANFORD. (Internet). Disponível em: https://dschool. stanford.edu/. Acesso em 23 de dezembro de 2017.

FASCIONI, Lígia. Você sabe o que é gestão do design? Disponível em https://www. ligiafascioni.com.br/voce-sabe-o-que-e-gestao-do-design. Acesso em: 22 dezembro 2017.

GIMENO, José Maria Ivañez. La gestión del diseño la empresa. Madrid: McGraw Hill, 2000.

INNOSUPPORT (Internet). Guia de Inovação. Disponível em: http:// www.innosupport. net/index.php?id=6047\&L=9\&no_cache $=1 \&$ sword list[0]=as\&sword_ list[1]=grandes\&sword_ list[2]=ideias Acesso em: 04 janeiro 2018.

Kelley, T., Littman, J. (2001) The art of innovation: lessons in creativity from IDEO, America's leading design firm. Currency/Doubleday.

KELLER, K. L. Strategic brand management: building, measuring, and managing brand equity. 2nd ed. New Jersey: Prentice Hall, 2003.

Kotler, P., \& Armstrong, G. (2018). Principles of marketing. Hoboken: Pearson Higher Education.

KOTLER, P. KELLER, K. L., Administração de marketing. 12. Ed. São Paulo: Pearson Hall, 2006.

LIEDTKA, J. (2018). Why Design Thinking Works. Harvard Business Review, 96(5), 72-79. Retrieved from http://widgets. ebscohost com/prod/customerspecific/ns000290/authentication/ index.php?url=https\%3a\%2f\%2fsearch.ebscohost.com\%2flogin. 
aspx\%3direct\%3dtrue\%26AuthType\%3dip\%2ccookie\%2cshib\%2cuid\%2 db\%3dheh\%26AN\%3d131356794\%26lang\%3dpt-br\%26site\%3dedslive\%26scope\%3dsite

Liedtka, J., King, A., Bennett, D. (2013) Solving Problems with Design Thinking: Ten Stories of What Works. Columbia University Press. LINDNER, Luís. Proposta de modelo de gestão de design para comunicação de valor. Trabalho de conclusão de curso de design, centro de comunicação e expressão. Florianópolis: UFSC, 2010.

LÖBACH, Bernd. Design Industrial: Bases para a configuração dos produtos industriais. Tradução Freddy Van Camp. São Paulo: Editora Blucher, 2001.

Lockwood, T., \& Papke, E. (2017). Innovation by Design How Any Organization Can Leverage Design Thinking to Produce Change, Drive New Ideas, and Deliver Meaningful Solutions. Franklin Lakes: Career Press.

MARTIN, Roger L. The Design of Business: Why Design Thinking is the Next Competitive Advantage. Harvard Business School Press, 2009. MARTINS, Rosane Fonseca de Freitas de; MERINO, Eugenio Andrés Díaz. A Gestão de Design como Estratégia Organizacional. Londrina: EDUEL, 2008.

MOZOTA, B. B. de. Gestão de design: usando o design para construir valor de marca e inovação corporativa. Porto Alegre: Bookman, 2011. PHILLIPS, Peter L. Brie ng: A gestão do projeto de design. São Paulo: Editora Blucher, 2008.

ROPELATO, M.; SILVEIRA, A. MACHADO, D. Inovação: Análise da Produção Científica Brasileira: Simpósio de Administração da Produção, Logística e Operações Internacionais. São Paulo, 2010.

Schumacher, T., \& Mayer, S. (2018). Preparing Managers for Turbulent Contexts: Teaching the Principles of Design Thinking. Journal of Management Education, 42(4), 496.

SCHUMPETER, Joseph A. Capitalismo, Sociedade e Democracia. 1 ed. São Paulo, Abril Cultural, 1988

VIANNA, Maurício et al. Design thinking: inovação em negócios. Rio de Janeiro: MJV Press, 2012. 162p.

WYLANT, Barry. Design Thinking and the Experience of Innovation. Massachusetts: Massachusetts Institute of Technology, v. 24, n.2, 2008. 


\section{Sara Gancho}

Sara Gancho é Professora Auxiliar no IADE, Universidade Europeia, onde lecciona disciplinas na área do Marketing, Gestão do Projeto, Gestão do Design e Design. É investigadora sênior no grupo de investigação IDEAS(R)EVOLUTION, pertencente à UNIDCOM/IADE unidade de investigação em Design e Comunicação. Trabalha nas áreas do Design, Marketing e relacionadas desde 2005.

\section{Monique Gasparelli}

Graduando Design Gráfico pela UNESP - Universidade Estadual Paulista "Júlio de Mesquita Filho" Campus Bauru. Tem experiência no desenvolvimento de projetos gráficos e de produtos.

Desde 2015 participa do Laboratório de Design Solidário, Labsol, desenvolvendo projetos e pesquisas nos campos do Design Solidário, Ecodesign, Design Sustentável, Design de Fantasias e Design de Moda.

Dentre os trabalhos elaborados no campo da moda, destaca-se o artigo premiado "A Joalheria Contemporânea e a Sustentabilidade na Produção de Ornamentos de Papel" Apresentado no $3^{\circ}$ Simpósio Interdesigners, no ano de 2016. 